\title{
Variability in the skeletal mineralogy of temperate bryozoans: the relative influence of environmental and biological factors
}

\author{
Jennifer Loxton ${ }^{1,2,3}$, Piotr Kuklinski ${ }^{2,4}$, Jens Najorka ${ }^{2}$, Mary Spencer Jones ${ }^{2}$, \\ Joanne S. Porter ${ }^{1,2, *}$ \\ ${ }^{1}$ Centre for Marine Biodiversity and Biotechnology, School of Life Sciences, Heriot-Watt University, Riccarton, \\ Edinburgh EH14 4AS, UK \\ ${ }^{2}$ Department of Life Sciences Millport, Natural History Museum, London SW7 5BD, UK \\ ${ }^{3}$ University Marine Biological Station, Millport, Isle of Cumbrae KA28 0EG, UK \\ ${ }^{4}$ Institute of Oceanology, Polish Academy of Sciences, Powstancow Warszawy 55, 81-712 Sopot, Poland
}

\begin{abstract}
Bryozoans exhibit a highly variable geochemistry within their calcium carbonate skeletons. Previous studies have predominantly attributed this variability to differences in seawater temperature influencing the relative deposition of aragonite and calcite, and the extent of magnesium incorporation into the calcite lattice. However, the patterns and scale of this variability have not been examined in detail. We conducted a high-replicate, multi-site study on the skeletal mineralogy of temperate Northern Hemisphere bryozoans to investigate the range of skeletal aragonite and $\mathrm{Mg}$-calcite variability between species and the relative influence of environmental and biological factors on skeletal biogeochemistry. During a cruise in May 2012 in Scapa Flow, Orkney, Northeast Scotland, 480 specimens from 3 bryozoan species were collected by SCUBA diving. Samples were obtained from 5 study sites with similar depths and physical characteristics. All specimens were collected within the same week and were selected to be of similar size, age and breeding status. The results of X-ray diffraction analysis showed that wt $\% \mathrm{MgCO}_{3}$ in calcite and wt $\%$ aragonite in total $\mathrm{CaCO}_{3}$ were statistically different between sites for all species. This may be explained by differential population connectivity between sites influenced by the tidal regimes of Scapa Flow. No temperate bryozoan species showed the expected positive trends of increasing wt $\% \mathrm{MgCO}_{3}$ in calcite or wt $\%$ aragonite in total $\mathrm{CaCO}_{3}$ with seawater temperature. Based on the data generated in this study, we suggest that both environmental and biological factors are involved in the control of skeletal mineralogy in some temperate bryozoan species.
\end{abstract}

KEY WORDS: Aragonite $\cdot$ Mg-calcite $\cdot$ Paleo-temperature $\cdot$ Magnesium

\section{INTRODUCTION}

Links between seawater temperature and the skeleton mineralogy of marine animals were first suggested by Clarke \& Wheeler (1922), when correlations were observed between the inorganic constituents of marine organisms and local habitat temperature. In 1954, increased magnesium incorporation in calcium carbonate was recognised as a proxy for increasing seawater temperature by Chave (1954). In the same year,
Lowenstam (1954) identified a positive correlation between seawater temperature and aragonite content in bimineralic animals. Substitution of $\mathrm{Mg}^{2+}$ for $\mathrm{Ca}^{2+}$ in calcite has been studied through inorganic precipitation studies, which demonstrate that incorporation of magnesium within the calcite lattice is thermodynamically more favourable in warmer waters (Chilanger 1962, Katz 1973, Burton \& Walter 1987, Mucci 1987, Oomori et al. 1987). Similarly, aragonite is more energetically expensive to build than calcite (Anderson \& 
Crerer 1993), resulting in an expectation of preferential deposition of aragonite over calcite under warmer conditions (Chave 1954). Positive correlations between Mg-calcite and/or aragonite and seawater temperature have been observed in a number of phyla, including Mollusca (Cohen \& Branch 1992), planktonic Foraminifera (Barker et al. 2005, Martínez-Botí et al. 2011), benthic Foraminifera (Rosenthal et al. 1997, Bohaty et al. 2012), coccoliths (Ra et al. 2010) and corals (Chang et al. 2004), leading to their development as paleoenvironmental thermometers.

The temperature of our oceans is changing globally (Kerr 2013) at a faster rate than has been seen in at least the past 420000 years (Hoegh-Guldberg \& Bruno 2010). It is anticipated that increasing seawater temperatures will result in an increase in the level of Mg-calcite and aragonite deposition in shells and skeletons (Chave 1954, Lowenstam 1954). In addition to getting warmer, our oceans are also acidifying. This is expected to result in reduced calcification rates and increased calcium carbonate dissolution in marine animals (Widdicombe \& Spicer 2008). Mg-calcite and aragonite are both more susceptible to dissolution than pure calcite (Anderson \& Crerer 1993). As a consequence, animals with higher Mg-calcite and greater utilization of aragonite may be more susceptible to ocean acidification in the future. Understanding the response of marine biogenic calcium carbonate to changes in environmental conditions may enable us to predict which species will survive under future climate change scenarios. By establishing a mineralogical baseline for some mineralogically complex, temperate marine animals, this study aims to enable future monitoring of the effects of climate change in temperate waters (Fabry et al. 2009).

Bryozoa constitute a phylum of modular filter-feeding animals in which there are a predicted 8000 extant species (Ryland 2005), the majority of which build complex calcium carbonate exoskeletons. Bryozoans exhibit a large mineralogical spectrum in their skeletons, which can be entirely calcitic, aragonitic or bimineralic, featuring both $\mathrm{CaCO}_{3}$ polymorphs (Smith et al. 2006, Lombardi et al. 2008). Magnesium (Mg) is naturally incorporated within bryozoan calcite and this can range from low $(\leq 4$ wt $\% \mathrm{MgCO}_{3}$ ), through intermediate (>4 wt\% $\mathrm{MgCO}_{3}$ to $<8 \mathrm{wt} \% \mathrm{MgCO}_{3}$ ) to high ( $\geq 8 \mathrm{wt} \% \mathrm{MgCO}_{3}$ ) (Smith et al. 2006, Kuklinski \& Taylor 2009), with most bryozoans featuring low or intermediate Mgcalcite (Smith et al. 2006, Lombardi et al. 2008, Kuklinski \& Taylor 2009, Taylor et al. 2009). Skeletal variability is exhibited at all taxonomic levels within the phylum with the majority of variability occurring between different clades and species. In all species, some mineralogical variation can be seen between different specimens and often within colonies.

Both biological and environmental controls are believed to influence bryozoan aragonite and Mgcalcite content within species, although the relative influence of these controls on skeleton composition is much debated. Biological control refers to factors such as astogeny (Smith et al. 1998, Kuklinski \& Taylor 2009, Smith \& Girvan 2010), growth rates (Smith 2007, Kuklinski \& Taylor 2008b), food availability (Bone \& James 1993), physiological 'wellness' (Stanley \& Hardie 1998) and directed adaptation to ecological niches in isolated populations (Cheetham et al. 1994). Environmental control indicates that skeletal mineralogy is driven by the seawater within which the bryozoan lives with little or no physiological involvement from the animal itself. Environmental factors influencing mineralogy may include salinity (Bohaty et al. 2012) and carbonate chemistry (Müller et al. 2014) in addition to temperature; however, temperature is assumed to be the dominant control when using wt $\% \mathrm{MgCO}_{3}$ in calcite or $\mathrm{wt} \%$ aragonite as paleoclimatic proxies (Chave 1954, Lowenstam 1954, Weiner \& Dove 2003).

Following the first reports of relationships between mineralogy and environmental conditions, it was observed that not all mineral deposition occurred in isotopic equilibrium and that 'the presence of a physiological effect in the case of certain groups of animals such as the echinoderms and corals, and plants, such as coralline algae, has seemed probable' (Epstein et al. 1951). This biological effect on mineralogy subsequently came to be known in biogeochemistry as the 'vital effect'. A strong vital effect can override, or mask, mineralogical responses to environmental factors such as temperature, compromising the usefulness of a species, or phylum, as a paleoclimatic recorder (Weiner \& Dove 2003). Past bryozoan studies have alluded to the existence of a vital effect (Schafer \& Bader 2008, Kuklinski \& Taylor 2009, Taylor et al. 2009, Smith \& Girvan 2010, Loxton et al. 2014); however, the relative influence of biological and environmental control on skeletal mineralogy has not yet been established. Past mineralogical studies on temperate bryozoans have been constrained by limited availability of samples and environmental measurements, and as a consequence, it has not been possible to clearly determine the usefulness of the Bryozoa as paleoenvironmental recorders.

The overall aim of this study was to conduct a highreplicate, multi-site study on the skeletal mineralogy of selected temperate bryozoans to allow compar- 
isons to be drawn between the mineralogy and range of skeletal variability between species, and to investigate the relative influence of environmental and biological factors on skeleton chemistry. The study was conducted over a relatively small spatial scale of $12 \mathrm{~km}$, and the reported environmental homogeneity of the study location (Bennett \& Covey 1998) leads us to predict that no environmentally driven differences in skeletal mineralogy between sites will be observed. Any differences in skeletal Mg-calcite, or aragonite, which do occur between sites, could therefore be attributed to biological control of skeletal mineralogy.

To investigate this, samples of 3 temperate bryozoan species were collected and examined from 5 sites in Scapa Flow, Orkney, Scotland. Multi-year measurements of seawater temperature in Scapa Flow were recorded at 2 depths to establish interseasonal variability and any effect of depth. Further environmental parameters of seawater temperature, depth and salinity were recorded at each site at the time of specimen collection. Water samples were collected at each site for laboratory analysis and calculation of carbonate system parameters. The resulting datasets were examined to (1) compare the mineralogy and range of skeletal $\mathrm{Mg}$-calcite and aragonite variability between the 3 temperate species, (2) investigate the relationship between bryozoan wt\% $\mathrm{MgCO}_{3}$ in calcite, wt\% aragonite in total $\mathrm{CaCO}_{3}$ and environmental factors, and (3) identify potential biological factors influencing temperate bryozoan mineralogy. This study will establish a mineralogical baseline for 3 common British bryozoans for comparison in future studies.

\section{MATERIALS AND METHODS}

\section{Study area}

Orkney is an archipelago of islands situated $16 \mathrm{~km}$ northeast of mainland Scotland (58 to $59^{\circ} \mathrm{N}, 2$ to $3^{\circ}$ W), at the point of confluence of North Atlantic and North Sea waters (Fig. 1A). At the centre of this island group lies Scapa Flow, a semi-enclosed marine basin covering an area of $\sim 130 \mathrm{~km}^{2}$ (Joyce 2004), where water depths reach a maximum of $70 \mathrm{~m}$. Tides and currents circulate through Hoy Sound, in the northwest, and Hoxa Sound in the south, which open to the Atlantic Ocean and Pentland Firth, respectively. Benthic sea temperature is highly variable throughout the year with a reported range from 5 to $14^{\circ} \mathrm{C}$ (Bennett \& Covey 1998). The salinity regime of
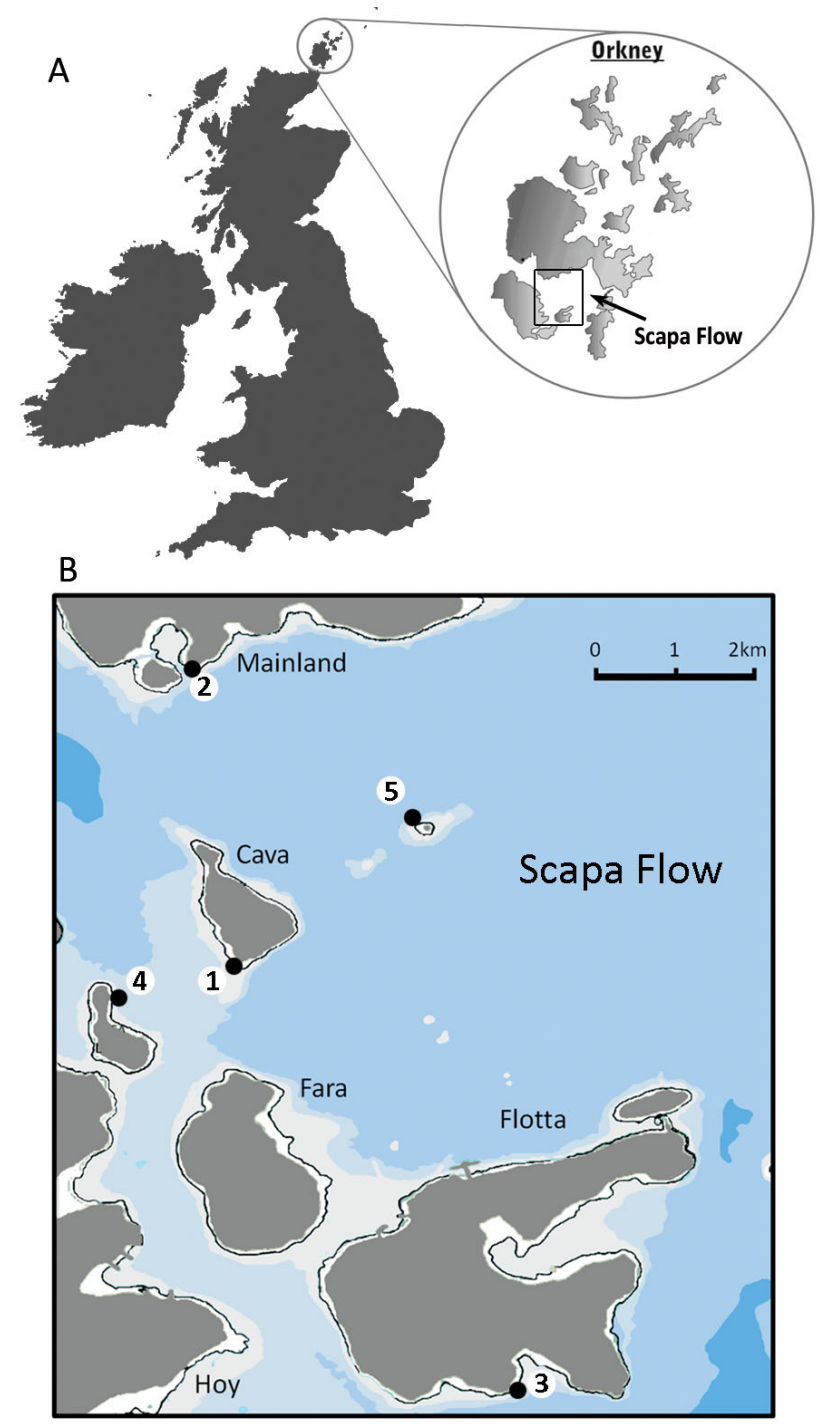

Fig. 1. Location of the study sites. (A) Location of the Orkney Islands and Scapa Flow in the northeast of Scotland. (B) Location of the study sites (1 to 5 ) in Scapa Flow ( $3^{\circ} 02^{\prime} 5^{\prime \prime} \mathrm{W}$ to $3^{\circ} 12^{\prime} 5^{\prime \prime} \mathrm{W}$ and $58^{\circ} 48^{\prime} \mathrm{N}$ to $\left.58^{\circ} 55^{\prime} \mathrm{N}\right)$. Bathymetry is indicated: pale blue $<10 \mathrm{~m}$, light blue $=10-20 \mathrm{~m}$, blue $=20-50 \mathrm{~m}$, dark blue $=50-100 \mathrm{~m}$

near bottom waters varies annually from 30 to $35 \mathrm{psu}$ (Bennett \& Covey 1998). More detail on the profile of the Orkney marine environment was published by Jones (1975).

\section{Sampling and specimen processing protocol}

Between October 2010 and March 2013, hourly seawater temperature measurements were recorded using a HOBO UA-002-64 temperature logger at 6 and $12 \mathrm{~m}$ benthic sites in Scapa Flow $(6 \mathrm{~m}$ site: $58^{\circ} 55.300^{\prime} \mathrm{N}, 3^{\circ} 06.579^{\prime} \mathrm{W}$; $12 \mathrm{~m}$ site: $58^{\circ} 55.273^{\prime} \mathrm{N}$, 
$\left.3^{\circ} 06.548^{\prime} \mathrm{W}\right)$. Logger accuracy is reported to be $0.5^{\circ} \mathrm{C}$ for temperature (measurable range -20 to $70^{\circ} \mathrm{C}$ ) (HOBO ${ }^{\circledR}$ Pendant Temperature/Light Data Logger (UA-002-xx) manual, p 1-3).

All sample collecting took place by SCUBA in a single week in May 2012. Five collection sites (1 to 5) were selected within Scapa Flow with similar depths $(9.5 \pm 3.5 \mathrm{~m})$ and substrate (boulders and cobbles) (Fig. 1B). All sample sites had similar exposure and geomorphology. At each site, specimens were collected on pebbles from below the kelp line from within a $5 \mathrm{~m}^{2}$ area at constant depth. Sites were an average of $6 \mathrm{~km}$ apart (range: 1.7 to $11.8 \mathrm{~km}$ ), and were within an area of $28.3 \mathrm{~km}^{2}$. Conductivity and temperature were measured at each site during collection using a HOBO U24-002 salt water conductivity logger; instrument accuracy is reported to be $0.1^{\circ} \mathrm{C}$ for temperature (measurable range -2 to $36^{\circ} \mathrm{C}$ ) and $3 \%$ of conductivity reading (HOBO ${ }^{\circledR} \mathrm{U} 24$ Conductivity Logger (U24-002-C) manual, p 2-7). Conductivity was converted to practical salinity units, as defined on the practical salinity scale of 1978 (Mcdougall et al. 2010) using the Gibbs function of seawater. In situ water samples were collected by SCUBA from each site in $500 \mathrm{ml}$ borosilicate glass bottles. To prevent any further biological activity in the stored sample, each sample was poisoned within $1 \mathrm{~h}$ of collection with a saturated solution of mercuric chloride ( $7 \mathrm{~g}$ per $100 \mathrm{ml}$ deionised water) in a $0.02 \%$ volume ratio. Carbonate analysis was undertaken at the National Oceanography Centre, Southampton following the protocols of Dickson et al. (2007). Dissolved inorganic carbon (DIC) was determined using coulometric titration; total alkalinity (TA) was determined using closed-cell titration. The precision of DIC and TA measurements obtained using this method is reported as $\pm 0.05 \%$ or better (Dumousseaud et al. 2011). The measurement of DIC, TA, temperature and salinity allows the calculation of the other variables of the carbonate system through the use of thermodynamic constants. The CO2SYS program (Lewis \& Wallace 1998) was used for the recalculation of the carbonate system variables using the thermodynamic constants of Mehrbach et al. (1973) refitted by Dickson \& Millero (1987). Carbonate analysis was conducted according to the methods of Dumousseaud et al. (2011).

A total of 480 specimens of 3 bryozoan species were collected for mineralogical examination. The species selected for analysis from Orkney were the cheilostomatous bryozoans Microporella ciliata, sensu stricto (Pallas, 1766), Membraniporella nitida (Johnston, 1838) and Escharella immersa (Fleming, 1828).
The study species were selected on the basis of being well-known, common species with distinctive features for identification (Fig. 2). The 3 species represent both calcitic and bimineralic mineralisers and were present in sufficient quantities for sampling during the experimental period. $M$. ciliata and $M$. nitida are both reported to have highest levels of settlement in the spring and summer (Maughan \& Barnes 2000, Denitto et al. 2007), while, between 2010 and 2013, the authors observed E. immersa as having a predominantly winter breeding cycle. Growth rate data are not available for E. immersa or M. nitida; however, Ball et al. (1995) estimate M. ciliata to grow at a rate of $1 \mathrm{~mm} \mathrm{mo}^{-1}$.

Specimens were identified to species level under a dissection (stereo) microscope (Zeiss) using the monographs of Hayward \& Ryland $(1998,1999)$ and the re-description of Microporella by Kuklinski \& Taylor (2008a). All specimens were alive when collected and were subsequently rinsed in fresh water and air dried for a minimum of 1 mo before samples were extracted for analysis. To minimise any potential mineralogical variability caused by season or specimen age, individual colonies of similar diameter were selected for sampling. Each sample consisted of $\sim 5$ zooids extracted from the outermost growing edge of a colony, containing the most recently deposited skeletal material. As far as possible, care was taken to ensure that no substrate (e.g. coralline algae) or epibionts were included within the sample, as they could potentially contaminate results through their added mineralogies.

Voucher specimens and extracted skeletal material have been lodged in the Bryozoa collections of the Natural History Museum, London (NHM) under registration numbers NHMUK 2014.1.10.261-331, 2014.1.10.332-422, 2014.1.10.575-634, 2014.1.10.683725 and 2014.1.10.727-813.

\section{Analysis techniques}

Mineralogical analyses were conducted at the EMMA unit (NHM London) using an Enraf-Nonius X-ray diffractometer (XRD) with an INEL CPS-120 curved position-sensitive detector and cobalt X-ray source. Tube operation conditions were $40 \mathrm{kV}$ and $40 \mathrm{~mA}$. A primary germanium 111 monochromator (INEL) with slit settings of $0.14 \times 5 \mathrm{~mm}$ was used to confine the X-ray beam to pure $\mathrm{Co} \mathrm{Ka}_{1}$ radiation. Samples were measured in reflection using asymmetric flat-plate geometry. Diffracted intensities were collected simultaneously over a $2-\theta$ range of 

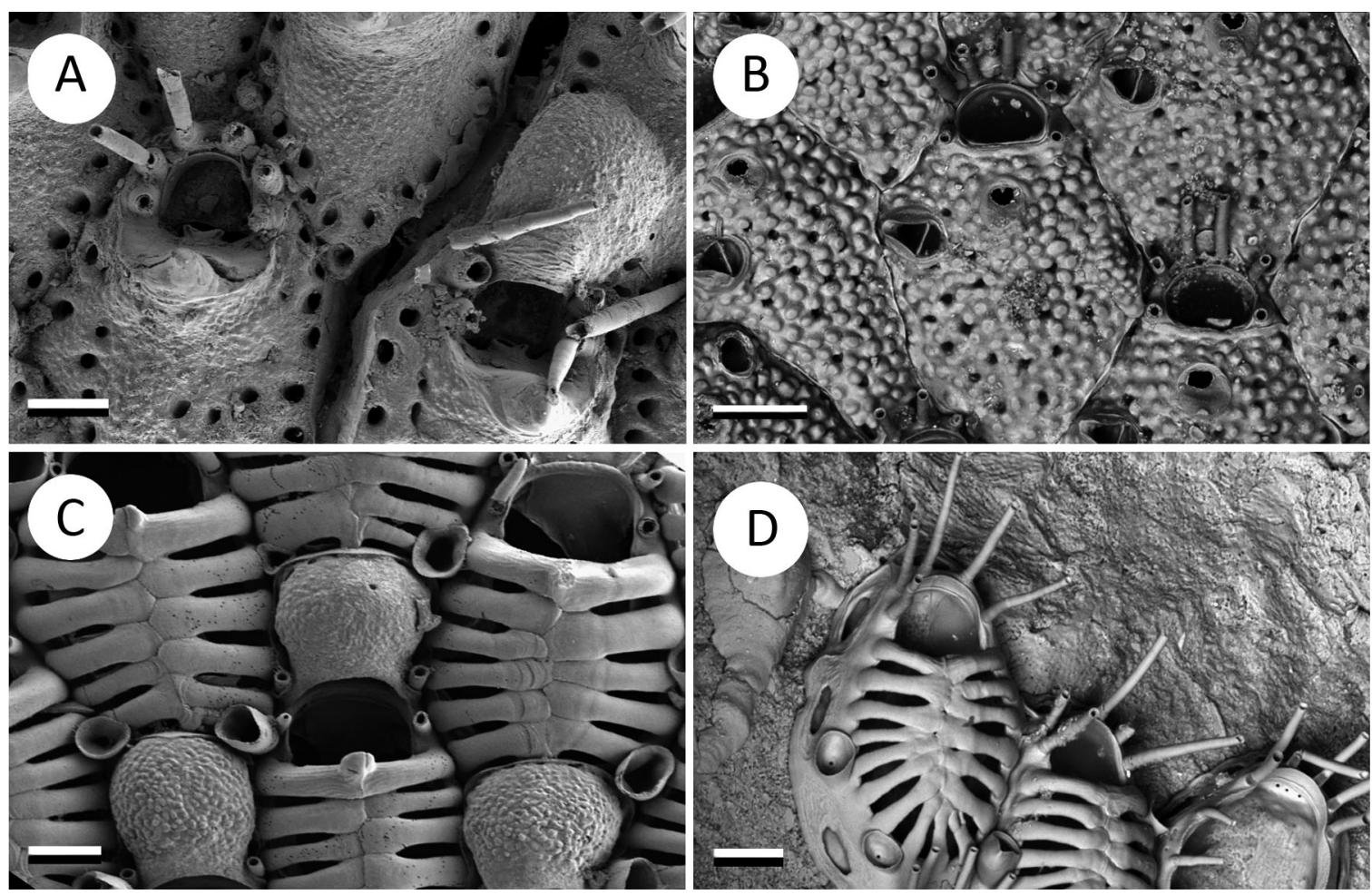

Fig. 2. Scanning electron microscope images of lightly bleached specimens of the study species. (A) Escharella immersa, scale $=100 \mu \mathrm{m}$. (B) Microporella ciliata, scale $=100 \mu \mathrm{m}$. (C,D) Membraniporella nitida, scale $=100 \mu \mathrm{m}$. Panel D shows early ontogeny

$120^{\circ}$ without angular movement of tube, sample or detector. The angle between the incoming monochromatic beam and sample holder was kept constant at $5.9^{\circ}$. The sample holder was rotated to increase the number of crystallites and the randomness of their orientations in the X-ray beam. The angular linearity of the position-sensitive detector was calibrated using silver behenate $\left(\mathrm{AgC}_{22} \mathrm{H}_{43} \mathrm{O}_{2}\right)$ and NIST silicon powder (SRM 640) as external standards and the calibration curve was fitted using a least-squares cubic spline function.

Bryozoan samples were powdered using an agate pestle and mortar and affixed using a drop of acetone to single quartz crystal substrates. Quantitative XRD analysis was undertaken to determine the dominant calcium carbonate polymorph, the proportions of calcite and aragonite in bimineralic species, and the $\mathrm{Mg}$ content of the calcite.

To determine the proportions of aragonite and calcite in bimineralic species, peak intensities were fitted to standard patterns generated from $100 \%$ aragonite and $100 \%$ calcite. Results are presented as $\mathrm{wt} \%$ aragonite, which is the proportion of the total calcium carbonate that is represented by the polymorph, aragonite. The error associated with this method is estimated to be $2 \%$ based on repeatability studies of samples with a known aragonite proportion (Kuklinski \& Taylor 2009). To calculate wt\% $\mathrm{MgCO}_{3}$ in calcite, the position of the d104 peak was measured, assuming a linear interpolation between calcite $\left(\mathrm{CaCO}_{3}\right)$ and $\mathrm{Mg}$-calcite $\left(\mathrm{MgCO}_{3}\right)$. Wt\% $\mathrm{MgCO}_{3}$ in calcite is the proportion of the total calcite $\left(\mathrm{Ca}_{(1-x)} \mathrm{Mg}_{(x)} \mathrm{CO}_{3}\right)$ within which the $\mathrm{Ca}^{2+}$ ion has been substituted for an $\mathrm{Mg}^{2+}$ ion. Mackenzie et al. (1983) validated the linear relationship between d104 and Mg content as accurate in the compositional range up to $17.4 \mathrm{wt} \% \mathrm{MgCO}_{3}$ in calcite; above this range there is nonlinear behaviour. Previous measurements of bryozoan $\mathrm{MgCO}_{3}$ in calcite have ranged between 0 and $13.7 \mathrm{wt} \%$ (Smith et al. 2006) - within the validated linear range. Composition information is considered accurate to within $2 \%$ on a well-calibrated instrument (Kuklinski \& Taylor 2009). Data evaluation was undertaken using WinXPow software.

\section{Statistics and data analysis}

The 6 and $12 \mathrm{~m}$ long-term temperature data series were statistically compared using a general linear model ANOVA. 


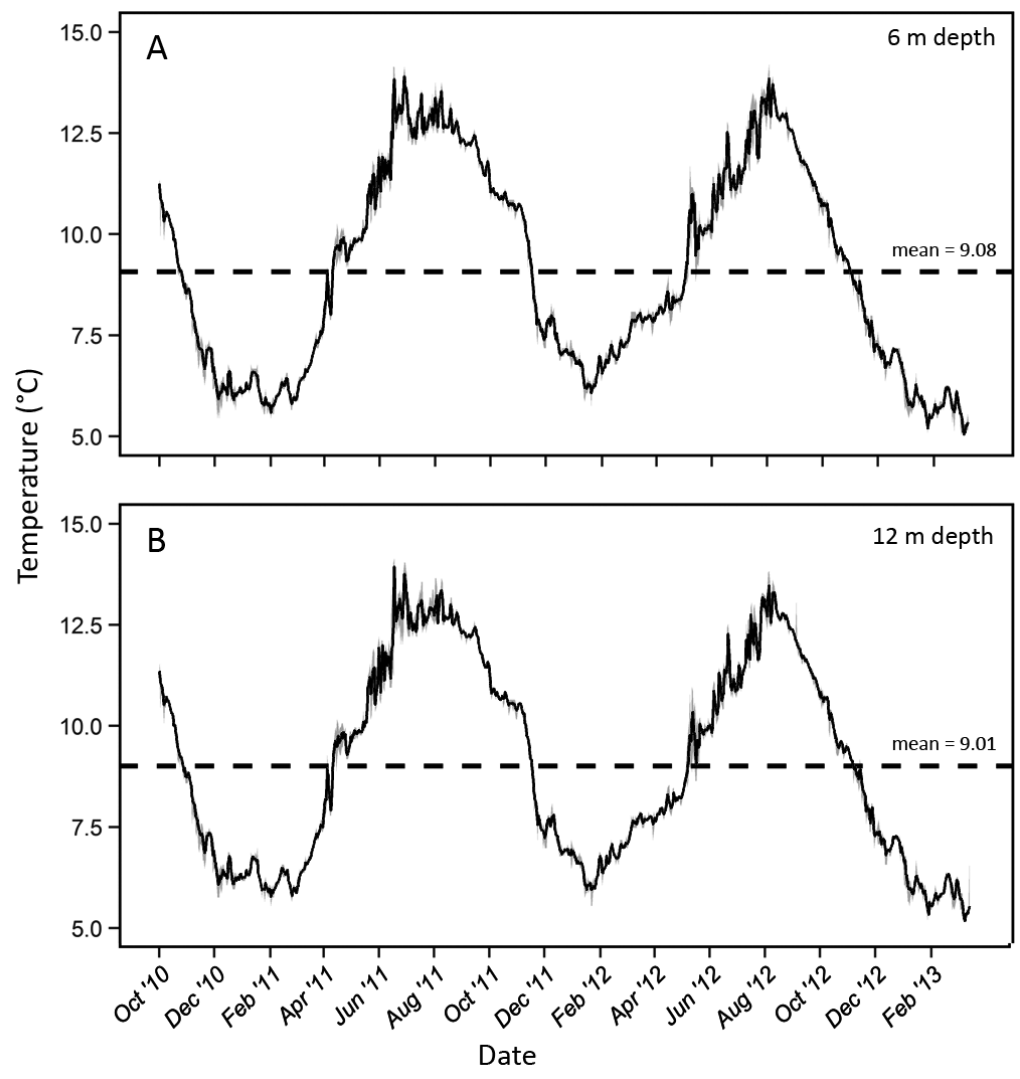

Fig. 3. Benthic seawater temperature in Scapa Flow at (A) 6 and (B) $12 \mathrm{~m}$ depths. Data were collected between October 2010 and March 2013. The black line indicates mean midday temperature; grey shading shows daily maximum and minimum temperatures. Multi-year mean is indicated with a dashed line mental variables were explored using the Kendall correlation method. P-values for all analyses were calculated based on the probability of error of 0.05 . All statistical data analysis was conducted in the $\mathrm{R}$ programming environment ( $\mathrm{R}$ Core Team 2013).

\section{RESULTS}

\section{Environmental analysis}

The long-term data series showed no statistical difference (ANOVA) between 6 and 12 m depths (Fig. 3).

Temperature data measured during sample collection at the sites was compared with data from the same date and time $( \pm 2 \mathrm{~h})$ extracted from the long-term data series at $12 \mathrm{~m}$ depth. The site data was found to deviate from the long-term data by a mean of just $0.12^{\circ} \mathrm{C}$ (maximum deviation $=$ $0.208^{\circ} \mathrm{C}$, minimum deviation $=0.054^{\circ} \mathrm{C}$ ) .

Environmental measurements taken from the individual sites also show little seawater temperature variability between sites (mean $=8.23^{\circ} \mathrm{C}, \mathrm{SD}= \pm 0.07^{\circ} \mathrm{C}$ ) with only slightly higher variability in salinity (mean = $33.01 \mathrm{psu}, \mathrm{SD}= \pm 0.49 \mathrm{psu}$ ) (Table 1).
All mineralogical measurements underwent weighted average transformation in the context of beta regression following the methodology of Smithson \& Verkuilen (2006). This initial transformation, $(y(n-1)+0.5) / n$, ensured that no data points equalled 0 or 1 and prepared the data for subsequent transformation using the logit function. The logit function, $\operatorname{logit}(p)=\ln (p /[1-p])$, accounts for the mineralogical measurements being proportional data $(p)$ (Warton \& Hui 2011).

Mineralogy data were tested for normality using Anderson-Darling normality tests and homogeneity of variance using Levine's test of equal variance. Mineralogy measurements were found to be normally distributed in most cases, but failed Levine's test of equal variance. The criteria for parametric testing were not satisfied for the mineralogical measurements; therefore, data were analysed using nonparametric tests. Variance was tested using Kruskal 1-way ANOVA with post hoc pair-wise testing (Mann-Whitney $U$-test). Correlations with environ-

\section{Species mineralogy}

In this study, the wt $\% \mathrm{MgCO}_{3}$ in calcite and wt $\%$ aragonite in $\mathrm{CaCO}_{3}$ of 480 specimens of 3 bryozoan species was quantified. All of the species, Membraniporella nitida $(\mathrm{n}=139)$, Microporella ciliata $(\mathrm{n}=145)$ and Escharella immersa ( $\mathrm{n}=146$ ), were found to have intermediate $\mathrm{Mg}$-calcite (4 to $8 \mathrm{wt} \% \mathrm{MgCO}_{3}$ in calcite) with a mean wt $\% \mathrm{MgCO}_{3}$ in calcite $( \pm \mathrm{SD})$ of $6.25( \pm 0.648), 6.88( \pm 0.638)$ and $5.66( \pm 0.612)$, respectively (Fig. 4).

One of the species, $M$. nitida, was found to be entirely calcitic. M. ciliata and E. immersa were both found to be calcite-dominated bimineralisers with varying volumes of aragonite present. $M$. ciliata was found to contain levels of aragonite ranging between 1 and $66 \mathrm{wt} \%$ (mean $=22.7 \mathrm{wt} \%, \mathrm{SD}= \pm 18.96 \mathrm{wt} \%$ ) of total $\mathrm{CaCO}_{3}$ present. E. immersa was likewise found to contain levels of aragonite ranging between 1 and $75 \mathrm{wt} \%($ mean $=31 \mathrm{wt} \%, \mathrm{SD}= \pm 18.69 \mathrm{wt} \%)$ of total $\mathrm{CaCO}_{3}$. 
Table 1. Physical and environmental characteristics for the 5 study sites at the time of collection. Missing carbonate data for site $5(-)$ is due to sample damage during collection. Dates given as d/mo/yr. Seawater scale used for $\mathrm{pH}$ measurements. DIC $=$ dissolved inorganic carbon; $\Omega_{\text {calcite }}=$ calcite saturation state

\begin{tabular}{|lccccc|}
\hline & $\begin{array}{c}\text { Site 1 } \\
\text { South Cava }\end{array}$ & $\begin{array}{c}\text { Site 2 } \\
\text { Holm of Houton }\end{array}$ & $\begin{array}{c}\text { Site 3 } \\
\text { Flotta }\end{array}$ & $\begin{array}{c}\text { Site 4 } \\
\text { Rysa Little }\end{array}$ & $\begin{array}{c}\text { Site 5 } \\
\text { Barrel of Butter }\end{array}$ \\
\hline Date & $03 / 05 / 2012$ & $09 / 05 / 2012$ & $10 / 05 / 2012$ & $06 / 05 / 2012$ & $03 / 05 / 2012$ \\
Temperature $\left({ }^{\circ} \mathrm{C}\right)$ & 8.222 & 8.274 & 8.334 & 8.19 & 8.1475 \\
Depth $(\mathrm{m})$ & 10.5 & 6 & 10 & 11 & 10 \\
Salinity $(\mathrm{psu})$ & 33.49 & 32.41 & 32.59 & 33.17 & 33.4 \\
Total alkalinity $\left(\mu \mathrm{kmol} \mathrm{kg}{ }^{-1}\right.$ seawater) & 2288.2 & 2293.3 & 2086.9 & 2290.4 & - \\
DIC $\left(\mu \mathrm{mol} \mathrm{kg}{ }^{-1}\right.$ seawater) & 2129.2 & 2096.3 & 2086.9 & 2085.5 & - \\
$\mathrm{pH}^{2-}\left(\mu \mathrm{mol} \mathrm{kg}{ }^{-1}\right.$ seawater) & 8.036 & 8.137 & 8.186 & 8.146 & - \\
$\mathrm{CO}_{3}{ }^{2-}(119.5$ & 143.5 & 159.8 & 147.6 & - \\
$\Omega_{\text {calcite }}$ & 2.87 & 3.46 & 3.85 & 3.55 & - \\
\hline
\end{tabular}

ANOVA analysis showed a statistically significant difference between species for both the wt $\% \mathrm{MgCO}_{3}$ in calcite $(\mathrm{p}<0.001, F=134.21)$ and the proportion of aragonite in total $\mathrm{CaCO}_{3}(\mathrm{p}<0.001, F=143.3)$.

\section{Mineralogical variability between sites}

Results of a Kruskall-Wallis 1-way ANOVA analysis showed that (a) the mean skeletal wt $\% \mathrm{MgCO}_{3}$ in calcite and (b) the mean wt $\%$ aragonite in total skeletal $\mathrm{CaCO}_{3}$ were different between sites for all 3 species (Table 2). Post hoc Mann-Whitney $U$-tests

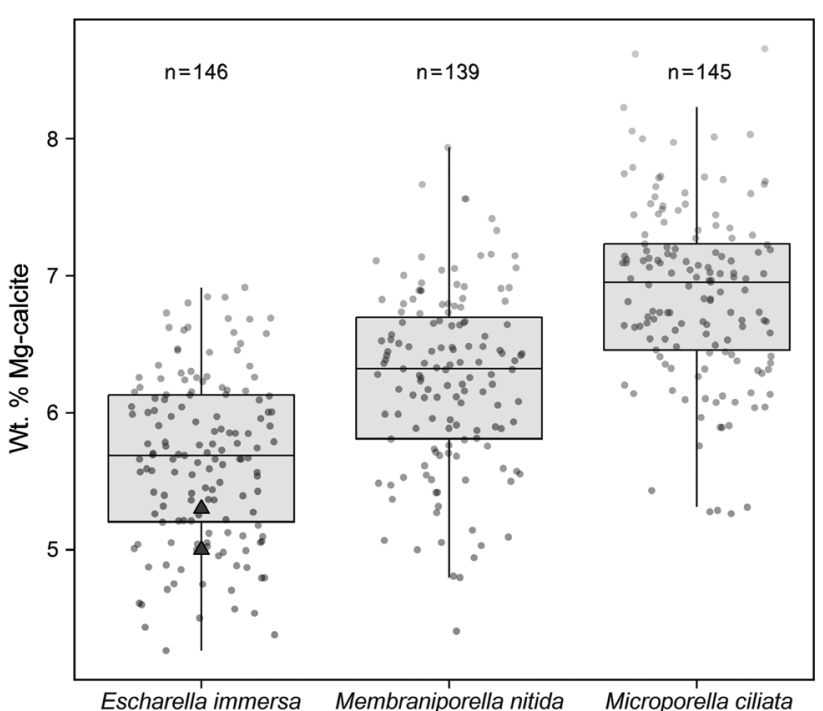

Fig. 4. Mean wt $\% \mathrm{MgCO}_{3}$ in calcite for the 3 temperate species. The box shows the standard deviation around the mean; the whiskers indicate the range. The scatterplot shows the spread of samples. Previous analyses by Taylor et al. (2009) are indicated with triangles showed that (a) wt $\% \mathrm{MgCO}_{3}$ in calcite and (b) the mean skeletal wt $\%$ aragonite in total $\mathrm{CaCO}_{3}$ showed exactly the same variability, being both statistically significantly different between sites in 18 out of 30 cases (Table 3).

Table 2. Kruskall Wallis 1-way ANOVA results testing (a) difference in wt $\% \mathrm{MgCO}_{3}$ in calcite, and (b) difference of wt $\%$ aragonite in total skeletal $\mathrm{CaCO}_{3}$, both for samples of a single species collected from different sites. All data were logit transformed prior to analysis

\begin{tabular}{|lcrr|}
\hline Species & df & $\chi^{2}$ & \multicolumn{1}{c|}{$\mathrm{p}$} \\
\hline (a) MgCO$_{3}$ in calcite & & & \\
Membraniporella nitida & 4 & 31.685 & $<0.0001$ \\
Microporella ciliata & 4 & 21.221 & 0.0003 \\
Escharella immersa & 4 & 43.643 & $<0.0001$ \\
(b) Aragonite & & & \\
Membraniporella nitida & 4 & 75.489 & $<0.0001$ \\
Microporella ciliata & 4 & 13.166 & 0.0105 \\
Escharella immersa & 4 & 23.814 & $<0.0001$ \\
\hline
\end{tabular}

Table 3. Results of Mann-Whitney post hoc analyses comparing (upper right) $\mathrm{wt} \% \mathrm{MgCO}_{3}$ in calcite, and (lower left) wt $\%$ aragonite in total $\mathrm{CaCO}_{3}$ between different sites. Significant differences between sites are indicated by the following symbols: (৩) Membraniporella nitida, (О) Microporella ciliata, (ם) Escharella immersa

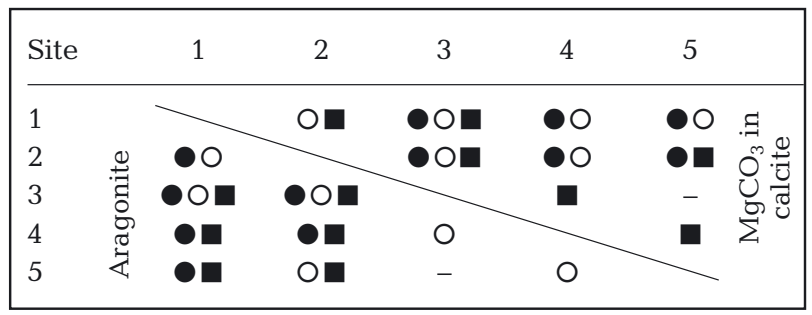


Examination of the Mann-Whitney post hoc analysis of both skeletal wt $\% \mathrm{MgCO}_{3}$ in calcite and wt $\%$ aragonite in total $\mathrm{CaCO}_{3}$ revealed that Sites 1 and 2, South Cava Island and Holm of Houton, were the most mineralogically distinct of all the study sites, differing statistically from 9 of the 12 species-site combinations. The least mineralogically distinct for both measures of skeletal mineralogy was Site 5, Barrel of Butter, which differed significantly in only 5 out of 12 species-site combinations.

Variability in skeletal $\mathrm{MgCO}_{3}$ in calcite and proportion of total $\mathrm{CaCO}_{3}$ consisting of aragonite between species and sites can be seen in Fig. 5. All species show the same skeletal mineralogical distinctness between sites, differing statistically in 50\% (6 out of 12) of sites. Although overall mineralogical distinctness is the same for wt\% aragonite in $\mathrm{CaCO}_{3}$ and wt $\% \mathrm{MgCO}_{3}$ in calcite, the species that are distinct between sites are different for the 2 mineralogical measurements.

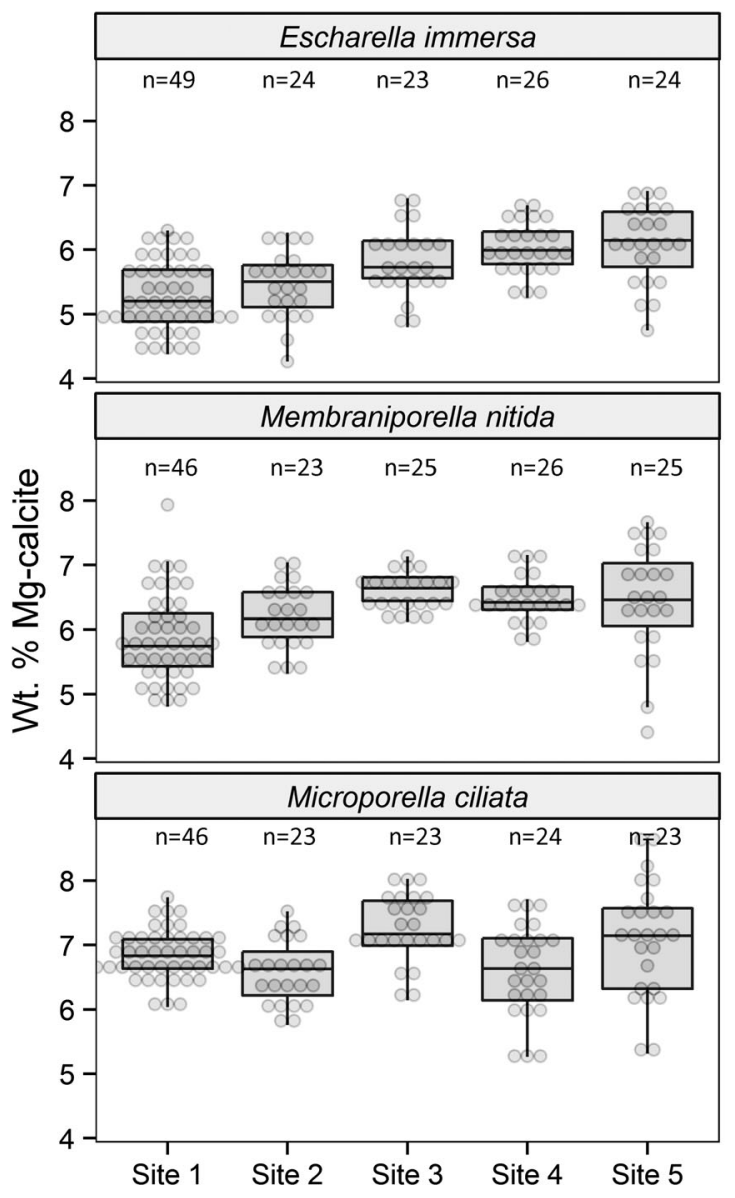

The skeletal composition of E. immersa showed a statistically significant negative correlation between site temperature and $\mathrm{wt} \% \mathrm{MgCO}_{3}$ in calcite and positive correlations between site salinity and TA with wt $\% \mathrm{MgCO}_{3}$ in calcite (Table 4). The skeletal composition of $M$. nitida showed a negative correlation between site salinity and $\mathrm{wt} \% \mathrm{MgCO}_{3}$ in calcite and positive correlations between $\mathrm{pH}_{1} \mathrm{CO}_{3}{ }^{2-}$ and calcite saturation state $\left(\Omega_{\text {calcite }}\right)$ with wt $\% \mathrm{MgCO}_{3}$ in calcite (Table 4).

The skeletal composition of E. immersa showed a negative correlation between $\mathrm{wt} \%$ aragonite in $\mathrm{CaCO}_{3}$ and site salinity, and positive correlations between wt $\%$ aragonite in $\mathrm{CaCO}_{3}$ and $\mathrm{pH}_{1} \mathrm{CO}_{3}{ }^{2-}$ and $\Omega_{\text {calcite }}$ (Table 4 ). As salinity decreases, and $\mathrm{pH}$, $\mathrm{CO}_{3}{ }^{2-}$ and $\Omega_{\text {calcite }}$ increase, there is an increase in wt $\%$ aragonite in skeletal $\mathrm{CaCO}_{3}$ (and a corresponding decrease in calcite). The skeletal composition of $M$. ciliata showed weak statistically significant correlations between wt $\%$ aragonite in $\mathrm{CaCO}_{3}$ and site

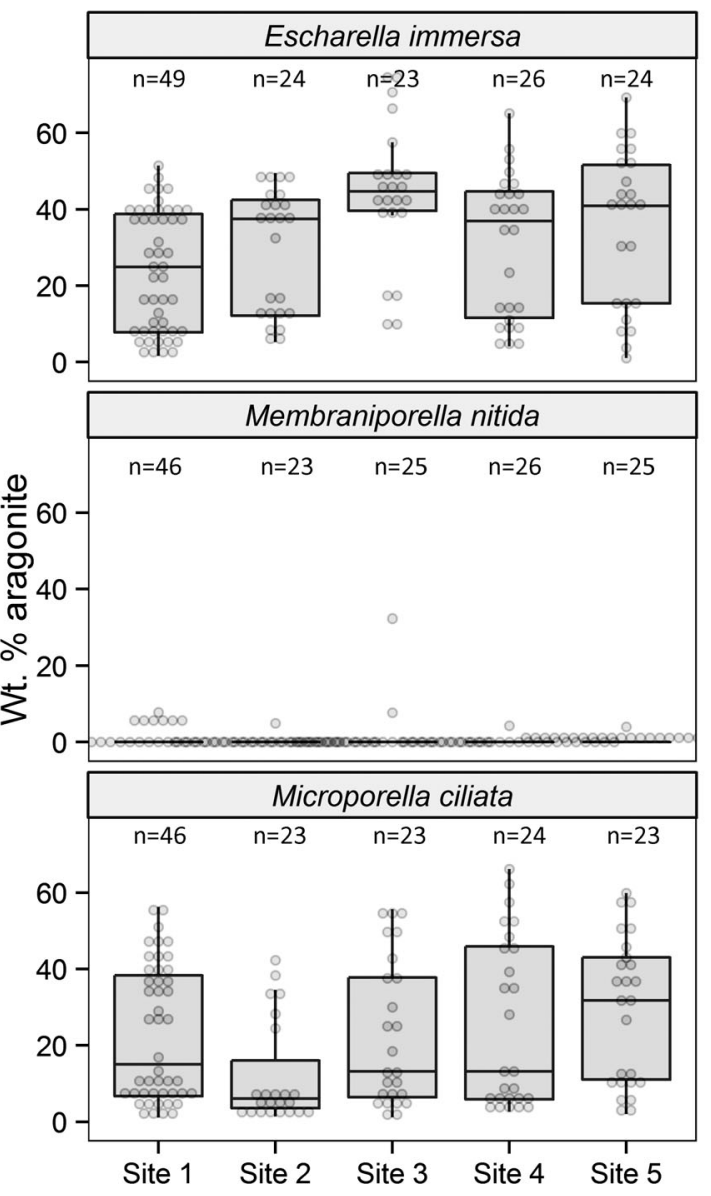

Fig. 5. Variability in wt $\% \mathrm{MgCO}_{3}$ in calcite (left) and wt\% aragonite in total $\mathrm{CaCO}_{3}$ (right) between the 3 temperate species and the 5 study sites. The box shows the standard deviation around the mean; the whiskers indicate the range; the scatterplot shows the spread of samples 
Table 4. Results of Kendall's correlation analysis comparing (1) wt $\% \mathrm{MgCO}_{3}$ in calcite and (2) wt\% aragonite in total $\mathrm{CaCO}_{3}$ for samples of single species to site environmental variables (Table 1). All mineralogy data were logit transformed prior to analysis. $\Omega_{\text {calcite }}=$ calcite saturation state; $\mathrm{x}=$ no statistically significant

\begin{tabular}{|c|c|c|c|c|c|c|}
\hline & $\begin{array}{l}\text { E. immersa } \\
\text { t }\end{array}$ & $\begin{array}{r}\% \mathrm{MgCO}_{3} \\
\text { M. nitida }\end{array}$ & $\overline{\text { M. ciliata }}$ & E. immersa & $\begin{array}{c}\% \text { aragonit } \\
M . \text { nitida }\end{array}$ & $\mathrm{e} \overline{\text { M. ciliata }}$ \\
\hline \multicolumn{7}{|c|}{ Temperature } \\
\hline $\begin{array}{l}\mathrm{p} \\
\tau\end{array}$ & $\begin{array}{r}0.002 \\
-0.191\end{array}$ & $\mathrm{x}$ & $\mathrm{x}$ & $\mathrm{x}$ & - & $\begin{array}{r}0.018 \\
-0.146\end{array}$ \\
\hline \multicolumn{7}{|c|}{ Depth } \\
\hline $\begin{array}{l}\mathrm{p} \\
\tau\end{array}$ & $\mathrm{x}$ & $\mathrm{x}$ & $\mathrm{x}$ & $\mathrm{x}$ & - & $\begin{array}{l}0.034 \\
0.131\end{array}$ \\
\hline \multicolumn{7}{|c|}{ Salinity } \\
\hline $\begin{array}{l}\mathrm{p} \\
\tau\end{array}$ & $\begin{array}{l}0.025 \\
0.138\end{array}$ & $\begin{array}{r}0.001 \\
-2.095\end{array}$ & $\mathrm{x}$ & $\begin{array}{r}0.005 \\
-0.173\end{array}$ & - & $\mathrm{x}$ \\
\hline \multicolumn{7}{|c|}{ Total alkalinity } \\
\hline $\begin{array}{l}\mathrm{p} \\
\tau\end{array}$ & $\begin{array}{l}0.007 \\
0.166\end{array}$ & $\mathrm{x}$ & $\mathrm{x}$ & $\mathrm{x}$ & - & $\mathrm{x}$ \\
\hline \multicolumn{7}{|l|}{$\mathrm{pH}$} \\
\hline $\mathrm{p}_{\tau}$ & $\mathrm{x}$ & $\begin{array}{l}0.002 \\
0.200\end{array}$ & $\mathrm{x}$ & $\begin{array}{l}0.028 \\
0.135\end{array}$ & - & $\mathrm{x}$ \\
\hline \multicolumn{7}{|c|}{$\mathrm{CO}_{3}{ }^{2-}$} \\
\hline $\begin{array}{l}\mathrm{p} \\
\tau\end{array}$ & $\mathrm{x}$ & $\begin{array}{l}0.002 \\
0.200\end{array}$ & $\mathrm{x}$ & $\begin{array}{l}0.028 \\
0.135\end{array}$ & - & $\mathrm{x}$ \\
\hline $\begin{array}{c}\Omega_{\text {calc }} \\
p \\
\tau\end{array}$ & $\mathrm{x}$ & $\begin{array}{l}0.002 \\
0.200\end{array}$ & $\mathrm{x}$ & $\begin{array}{l}0.028 \\
0.135\end{array}$ & - & $\mathrm{x}$ \\
\hline
\end{tabular}
correlation detected; $\mathrm{p}=\mathrm{p}$-value; $\tau=$ Kendall's tau; ' ${ }^{\prime}{ }^{\prime}=$ missing data

ascophorans, the calcitic species $M$. nitida is from the family Cribrilinidae. Previous mineralogical analysis of cribrilinid species have led to the family being reported as calcitic (Smith et al. 2006) and the data presented in this study confirm this. Although the species E. immersa and $M$. ciliata are not in the same taxonomic family, recent phylogenetic analysis by Waeschenbach et al. (2012) placed these bimineralic species within the same clade alongside Escharoides coccinea, Oshurkovia littoralis, Pentapora fascialis and Cryptosula pallasiana. Previous mineralogical studies on E. coccinea, O. littoralis, P. fascialis and C. pallasiana have shown them all to be bimineralic (Smith et al. 2006, Taylor et al. 2009) and the data presented in this study provide further evidence of the bimineralic propensity of this clade. The differences in mineralogy between species are, therefore, most likely to be attributable to their differential taxonomic and phylogenetic affinities.

temperature and depth. Wt\% aragonite in $\mathrm{CaCO}_{3}$ decreases (and calcite increases) with increasing temperature; wt $\%$ aragonite in $\mathrm{CaCO}_{3}$ increases (and calcite decreases) with increasing depth (Table 4).

\section{DISCUSSION}

In this study, a high-replicate, multi-site analysis of the skeletal mineralogy of temperate bryozoans from Orkney was conducted. This analysis allows comparisons to be drawn between the mineralogy and range of skeletal variability between species, and enables investigation of the relative influence of environmental and biological factors on skeleton chemistry.

The 3 study species were found to have statistically different mineralogies to each other with both wt\% $\mathrm{MgCO}_{3}$ in calcite and wt\% aragonite in $\mathrm{CaCO}_{3}$ differing significantly in all cases. Aragonite was present in Microporella ciliata and Escharella immersa, but absent in Membraniporella nitida. All species were found to have intermediate $\mathrm{Mg}$-calcite (4 to 8 wt $\% \mathrm{MgCO}_{3}$ in calcite). Although all species are
Analysis showed that mean skeletal wt\% $\mathrm{MgCO}_{3}$ in calcite and wt $\%$ aragonite in total $\mathrm{CaCO}_{3}$ were different between sites for all species. In this study, the relationship between environmental conditions and aragonite deposition was inconsistent between the 2 bimineralic species examined and no species showed the predicted positive relationship between temperature and aragonite deposition (Anderson \& Crerer 1993). The predicted positive relationship between seawater temperature and $\mathrm{wt} \% \mathrm{MgCO}_{3}$ in calcite was also not exhibited in any of the species examined. The relationships between Mg-calcite and temperature were found to be inconsistent between species, with responses 'bucking the trend' of what would be expected from the literature (Chave 1954, Lowenstam 1954) in some or all cases. Carbonate system parameters of $\mathrm{pH}_{1} \mathrm{CO}_{3}{ }^{2-}$ and $\Omega_{\text {calcite }}$ were shown to have positive correlations with wt\% aragonite in E. immersa and with wt $\% \mathrm{MgCO}_{3}$ in calcite in M. nitida. E. immersa also showed a positive correlation between $\mathrm{TA}$ and $\mathrm{wt} \% \mathrm{MgCO}_{3}$ in calcite. Investigations on cultured planktonic Foraminifera (Lea et al. 1999) and coccoliths (Müller et al. 2014) have reported a pattern of increasing $\mathrm{wt} \% \mathrm{MgCO}_{3}$ in calcite with decreasing $\mathrm{pH}$ and associated carbonate 
parameters; however, this pattern was not seen in any of the bryozoan species in this study. An in situ experiment on the bryozoan species Myriapora truncata by Lombardi et al. (2010) found $\mathrm{wt} \% \mathrm{MgCO}_{3}$ in calcite to decrease with decreasing $\mathrm{pH}$. Our study also detected this positive correlation; however, it was only significant in a single species and therefore cannot be considered reliable evidence of a relationship between skeletal mineralogy and carbonate system parameters in the Bryozoa.

As predicted, environmental conditions alone do not adequately explain the differences in wt\% $\mathrm{MgCO}_{3}$ in calcite or aragonite found between sites. As reported by Bennett \& Covey (1998), and confirmed in this study, Scapa Flow is found to have a high level of homogeneity in environmental parameters. Across the $12 \mathrm{~km}$ scale, only minimal variation in temperature and salinity was detected between sites and there was no significant difference between site measurements and the long-term dataset. Carbonate system parameters were also shown to have only a low level of variation between sites. Thermodynamic studies have shown that, where temperature is the only influencing factor, Mg incorporation within calcite can be expected to increase by $\sim 3 \%$ per $1{ }^{\circ} \mathrm{C}$ (Rosenthal et al. 1997). The temperature differences between sites in this study are fractions of a degree and so any increase in wt $\% \mathrm{MgCO}_{3}$ in calcite caused by temperature may be below the levels of detection. We suggest that the results presented in this study provide evidence that biological processes are influencing the process of $\mathrm{Mg}$-calcite and aragonite deposition in these temperate bryozoan species.

Two of the study species, M. nitida and E. immersa, showed contrasting responses of mineralogy to salinity. This dichotomy may be explained by the ecological preferences of the 2 species. E. immersa is only found in full salinity waters (Hayward \& Ryland 1999), while $M$. nitida has also been reported from brackish sample stations by Winston (1977). At lower salinities, E. immersa may be encountering some physiological and metabolic stress, reducing the energy available for skeleton construction and resulting in the reported decrease in aragonite and lower overall $\mathrm{Mg}$ incorporation in calcite. Conversely, in low-salinity conditions, $M$. nitida exhibits increased wt $\% \mathrm{MgCO}_{3}$ in its skeletal calcite and this may be evidence of the stable metabolic state of this species in diminished salinity conditions.

A potential explanation for the observed differences in mineral deposition between sites may be the hydrodynamic linkages between study locations. Orkney features a highly tidal hydrological regime.
The main tidal flows come in and out of Scapa Flow from the northwest and the south, both at an average flow rate of $\sim 0.25 \mathrm{~m} \mathrm{~s}^{-1}$ (Marine Scotland 2012). The island cluster in the west of Scapa Flow causes a complex funnelling of the tidal current between these sites. Fara, in particular, creates an almost cyclical flow around the island at all points of the tide and the south of Flotta is prone to eddies, as the southern tidal in-flow meets the ebbing flow from Fara (Orkney Islands Council 2013).

The least mineralogically distinct site was the Barrel of Butter, Site 5, which is in the centre of Scapa Flow and is, therefore, subject to incoming flow, larvae and gametes from both the south and the northwest. It is particularly indistinct from Flotta, Site 3, with no statistically significant difference in any species for either wt $\% \mathrm{MgCO}_{3}$ in calcite or wt\% aragonite in $\mathrm{CaCO}_{3}$, despite its geographical distance from Flotta $(>7.5 \mathrm{~km})$. Lecithotrophic larvae from the temperate bryozoan Celleporella hyalina, which are of a comparable size to the species used in this study, were found to be able to swim for up to $4 \mathrm{~h}$, with a preference to settle within $1 \mathrm{~h}$ of release (Goldson et al. 2001). If we expect similar planktonic behaviour for our comparably sized larvae, then during periods of peak tide, the dispersal potential would be up to $14.4 \mathrm{~km}$, with distances of over $3.6 \mathrm{~km}$ achieved in $1 \mathrm{~h}$. This would allow transport of larvae from Flotta to the Barrel of Butter in just over $2 \mathrm{~h}$, well within the feasible time limit for successful metamorphosis upon settlement (Wendt 2000). It is therefore possible that the mineralogical indistinctness between the Barrel of Butter and Flotta is caused by population interconnectivity. The most mineralogically distinct sites were South Cava (Site 1) and Holm of Houton (Site 2). The cyclical tidal flow around Fara appears strong at all points of the tide (Orkney Islands Council 2013) and may be acting to isolate South Cava and Holm of Houton from the south of Scapa Flow, helping to explain why all species from these sites are mineralogically distinct from Flotta populations. Population genetics and calculation of the level of gene flow between sites would need to be conducted on bryozoans from all sites to test this hypothesis.

\section{CONCLUSIONS}

Using mineralogical analysis, we detected a high degree of variability in the wt $\% \mathrm{MgCO}_{3}$ in calcite and $\mathrm{wt} \%$ aragonite in the skeletons of marine bryozoans sampled from Orkney, Scotland. Among species differences in mineralogy provide evidence for 
the vital effect in some temperate bryozoans. Significant variability was found to occur between sites and, in some cases, was found to be related to seawater temperature, salinity and carbonate system parameters. Detected patterns between mineralogy and environmental conditions were inconsistent, however, and we suggest that differences in population connectivity and physical hydrography between sites may be additionally influencing skeletal mineralogy. Although the underlying mechanisms remain unclear, we suggest that physiological processes may be overriding or masking environmental patterns in some bryozoan species. Our study emphasizes the importance of sampling replication and accurate measurement of environmental conditions, as well as consideration of species and site-specific biological factors when discussing mineralogical variability. Exploring the role of both biological and environmental factors in the control of calcium carbonate mineralogy should continue to provide a fertile area for research in the future.

Acknowledgements. We thank the Marine Alliance for Science and Technology in Scotland (MASTS) and the Marine Environmental Research Group (MERG) at Heriot-Watt University for supporting and funding this $\mathrm{PhD}$ and the NERC Collaborative Gearing Scheme, Heriot-Watt Alumni Fund and Catlin Group Limited who financed and sponsored this project. P.K. thanks the programme 'Mobilnosc Plus' (606/MOB/2011/0) of the Polish Ministry of Science and Higher Education, which enabled completion of the study. Special thanks are extended to the divers of the Heriot-Watt Scientific Diving Team and the crew of the MV 'Valkyrie' for fieldwork support.

\section{LITERATURE CITED}

Anderson GM, Crerer DA (1993) Standard state thermodynamic properties of selected minerals and other compounds. In: Anderson GM, Crerer DA (eds) Thermodynamics in geochemistry: the equilibrium model. Oxford University Press, New York, NY, p 547-552

Ball BJ, Costelloe J, Konnecker G, Keegan BF (1995) The rocky subtidal assemblages of Kinsale Harbour (South coast of Ireland). In: Eleftheriou A, Smith C, Ansell AD (eds) Biology and ecology of shallow coastal waters. Proc 28th European Marine Biology Symp, Institute of Marine Biology of Crete, Iraklio, Crete 1993. Olsen \& Olsen, Fredensborg

Barker S, Cacho I, Benway H, Tachikawa K (2005) Planktonic foraminiferal $\mathrm{Mg} / \mathrm{Ca}$ as a proxy for past oceanic temperatures: a methodological overview and data compilation for the Last Glacial Maximum. Quat Sci Rev 24: 821-834

Bennett TL, Covey R (1998) Orkney (MNCR Sector 2). In: Bennett TL, Covey R (eds) Marine nature conservation review. Benthic marine ecosystems of Great Britain and the north-east Atlantic. Joint Nature Conservation Committee, Peterborough, p 109-117
Bohaty SM, Zachos JC, Delaney ML (2012) Foraminiferal $\mathrm{Mg} / \mathrm{Ca}$ evidence for Southern Ocean cooling across the Eocene-Oligocene transition. Earth Planet Sci Lett 317-318:251-261

- Bone Y, James N (1993) Bryozoans as carbonate sediment producers on the cool-water Lacepede shelf, Southern Australia. Sediment Geol 86:247-271

Burton EA, Walter LM (1987) Relative precipitation rates of aragonite and $\mathrm{Mg}$ calcite from seawater: Temperature or carbonate ion control? Geology 15:111-114

Chang VTC, Williams RJP, Makishima A, Belshawl NS, O'Nions RK (2004) Mg and Ca isotope fractionation during $\mathrm{CaCO}_{3}$ biomineralisation. Biochem Biophys Res Commun 323:79-85

> Chave KE (1954) Aspects of the biogeochemistry of magnesium.1: Calcareous marine organisms. J Geol 62:266-283

> Cheetham AH, Jackson JBC, Hayek LAC (1994) Quantitative genetics of bryozoan phenotypic evolution. II. Analysis of selection and random change in fossil species using reconstructed genetic parameters. Evolution 48:360-375

Chilanger GV (1962) Dependence on temperature of Ca/Mg ratio of skeletal structures in organisms and direct chemical precipitates of sea water. Bull South Calif Acad Sci 61:45-61

Clarke FW, Wheeler WC (1922) The inorganic constituents of marine invertebrates. US Geol Surv Prof Pap 124:34-36

> Cohen AL, Branch GM (1992) Environmentally controlled variation in the structure and mineralogy of Patella granularis shells from the coast of southern Africa: implications for palaeotemperature assessments. Palaeogeogr Palaeoclimatol Palaeoecol 91:49-57

> Denitto F, Terlizzi A, Belmonte G (2007) Settlement and primary succession in a shallow submarine cave: spatial and temporal benthic assemblage distinctness. Mar Ecol 28:35-46

- Dickson AG, Millero FJ (1987) A comparison of the equilibrium constants for the dissociation of carbonic acid in seawater media. Deep-Sea Res A 34:1733-1743

Dickson AG, Sabine CL, Christian JR (2007) Guide to best practices for ocean $\mathrm{CO}_{2}$ measurements. PICES Special Publication 3, IOCCP Report No. 8. North Pacific Marine Science Organization, Sidney

Dumousseaud C, Achterberg E, Tyrrell T (2011) Practical guide for the UK Ocean Acidification Research Programme (UKOARP) carbonate chemistry facility. National Oceanography Centre, Southampton. Available at www.noc.soton.ac.uk/ukoacf (accessed April 2012)

> Epstein S, Buchsbaum R, Lowenstam H, Urey HC (1951) Carbonate-water isotopic temperature scale. Geol Soc Am Bull 62:417-426

Fabry VJ, McClintock JB, Mathis JT, Grebmeier JM (2009) Ocean acidification at high latitudes: the bellwether. Oceanography (Wash DC) 22:160-171

Goldson AJ, Hughes RN, Gliddon CJ (2001) Population genetic consequences of larval dispersal mode and hydrography: a case study with bryozoans. Mar Biol 138: 1037-1042

Hayward PJ, Ryland JS (1998) Cheilostomatous Bryozoa, Part 1 Aeteoidea-Cribrilinoidea: notes for the identification of British species, Vol. 10. Field Studies Council, Shrewsbury

Hayward PJ, Ryland JS (1999) Cheilostomatous Bryozoa, Part 2 Hippothooidea-Celleporoidea: notes for the identification of British species, Vol. 10. Field Studies Council, Shrewsbury 
Hoegh-Guldberg O, Bruno JF (2010) The impact of climate change on the world's marine ecosystems. Science 328: 1523-1528

Jones AM (1975) The marine environment of Orkney. In: Jones AM (ed) Proc Nature Conservancy Council Symp, Edinburgh. Nature Conservancy Council, London, p 26-27

- Joyce LB (2004) Dinoflagellate cysts in recent marine sediments from Scapa Flow, Orkney, Scotland. Bot Mar 47: 173-183

Katz A (1973) The interaction of magnesium with calcite during crystal growth at $25-90^{\circ} \mathrm{C}$ and one atmosphere. Geochim Cosmochim Acta 37:1563-1586

Kerr RA (2013) The IPCC gains confidence in key forecast. Science 342:23-24

Kuklinski P, Taylor PD (2008a) Arctic species of the cheilostome bryozoan Microporella, with a redescription of the type species. J Nat Hist 42:1893-1906

Kuklinski P, Taylor PD (2008b) Are bryozoans adapted for living in the Arctic? In: Proc 14th Int Bryozoology Association Conference, Boone, California. Virginia Museum of Natural History Publications, Martinsville, VA, p 101-110

Kuklinski P, Taylor PD (2009) Mineralogy of Arctic bryozoan skeletons in a global context. Facies 55:489-500

> Lea DW, Mashiotta TA, Spero HJ (1999) Controls on magnesium and strontium uptake in planktonic foraminifera determined by live culturing. Geochim Cosmochim Acta 63:2369-2379

Lewis E, Wallace DWR (1998) Program developed for $\mathrm{CO}_{2}$ system calculations. ORNL/CDIAC-105. US Dept. of Energy, Oak Ridge, TN

Lombardi C, Cocito S, Hiscock K, Occhipinti-Ambrogi A, Setti M, Taylor PD (2008) Influence of seawater temperature on growth bands, mineralogy and carbonate production in a bioconstructional bryozoan. Facies 54: 333-342

Lombardi C, Rodolfo-Metalpa R, Cocito S, Gambi MC, Taylor PD (2010) Structural and geochemical alterations in the $\mathrm{Mg}$ calcite bryozoan Myriopora truncata under elevated seawater $\mathrm{pCO}_{2}$ simulating ocean acidification. Mar Ecol 32:1-11

Lowenstam HA (1954) Environmental relations of modification compositions of certain carbonate secreting marine invertebrates. Proc Natl Acad Sci USA 40:39-48

Loxton J, Kuklinski P, Barnes DKA, Najorka J, Spencer Jones M, Porter JS (2014) Variability of Mg-calcite in Antarctic bryozoan skeletons across spatial scales. Mar Ecol Prog Ser 507:169-180

Mackenzie FT, Bischoff WD, Bishop FC, Loijens M, SchoonMaker J, Wollast R (1983) Magnesian calcites: low temperature occurrence, solubility and solid-solution behavior. In: Reeder RJ (eds) Carbonates: mineralogy and chemistry, Vol 11. Mineralogical Society of America, Chantilly, VA, p 97-143

Marine Scotland (2012) Tidal-Regional Locational Guidance, Part 3. Marine Scotland, Aberdeen. Available at www.scotland.gov.uk/Topics/marine/marineenergy/ Planning/tidalrlg (accessed December 2013)

Martínez-Botí MA, Mortyn PG, Schmidt DN, Vance D, Field DB (2011) Mg/Ca in foraminifera from plankton tows: evaluation of proxy controls and comparison with core tops. Earth Planet Sci Lett 307:113-125

Maughan BC, Barnes DKA (2000) Seasonality of competition in early development of subtidal encrusting communities. Mar Ecol 21:205-220
McDougall TJ, Feistel R, Millero FJ, Jackett DR and others (2010) The international thermodynamic equation of seawater 2010 (TEOS-10). Calculation and use of thermodynamic properties. Global Ship-Based Repeat Hydrography Manual, IOCCP Report 14, Institute of Oceanology of Polish Academy of Sciences, Sopot

> Mehrbach C, Culberson CH, Hawley JH, Pytkowicz RM (1973) Measurement of the apparent dissociation constants of carbonic acid in seawater at atmospheric pressure. Limnol Oceanogr 18:897-907

Mucci A (1987) Influence of temperature on the composition of magnesian calcite overgrowths precipitated from seawater. Geochim Cosmochim Acta 51:1977-1984

Müller MN, Lebrato M, Riebesell U, Barcelos e Ramos J and others (2014) Influence of temperature and $\mathrm{CO}_{2}$ on the strontium and magnesium composition of coccolithophore calcite. Biogeosciences 11:1065-1075

> Oomori T, Kaneshima H, Maezato Y (1987) Distribution coefficient of $\mathrm{Mg}^{2+}$ ions between calcite and solution at 10-50 ${ }^{\circ} \mathrm{C}$. Mar Chem 20:327-336

Orkney Islands Council (2013) Orkney Islands Council: Marine services. Orkney Islands Council, Scapa. Available at www.orkneyharbours.com/weather.asp? $t=5$ (accessed December 2013)

R Core Team (2013) R: a language and environment for statistical computing. R. Foundation for Statistical Computing, Vienna

> Ra K, Kitagawa H, Shiraiwa Y (2010) Mg isotopes and $\mathrm{Mg} / \mathrm{Ca}$ values of coccoliths from cultured specimens of the species Emiliania huxleyi and Gephyrocapsa oceanica. Mar Micropaleontol 77:119-124

Rosenthal Y, Boyle EA, Slowey N (1997) Temperature control on the incorporation of magnesium, strontium, fluorine, and cadmium into benthic foraminiferal shells from Little Bahama Bank: prospects for thermocline paleoceanography. Geochim Cosmochim Acta 61:3633-3643

Ryland JS (2005) Bryozoa: an introductory overview. In: Woss ER (ed) Moostiere (Bryozoa). Taylor \& Francis Group, London, p 9-20

Schafer P, Bader B (2008) Geochemical composition and variability in the skeleton of the bryozoan Cellaria sinuosa (Hassall): biological versus environmental control. In: Hageman SJ, Key MM, Winston JE (eds) Proc 14th Int Bryozoology Assoc Conf, Martinsville, Virginia. Virginia Museum of Natural History Publications, Martinsville, VA, p 269-279

Smith AM (2007) Age, growth and carbonate production by erect rigid bryozoans in Antarctica. Palaeogeogr Palaeoclimatol Palaeoecol 256:86-98

Smith AM, Girvan E (2010) Understanding a bimineralic bryozoan: skeletal structure and carbonate mineralogy of Odontionella cyclops (Foveolariidae: Cheilostomata: Bryozoa) in New Zealand. Palaeogeogr Palaeoclimatol Palaeoecol 289:113-122

Smith AM, Nelson CS, Spencer HG (1998) Skeletal carbonate mineralogy of New Zealand bryozoans. Mar Geol 151:27-46

> Smith AM, Key MM Jr, Gordon DP (2006) Skeletal mineralogy of bryozoans: taxonomic and temporal patterns. Earth Sci Rev 78:287-306

Smithson M, Verkuilen J (2006) Fuzzy set theory: applications in the social sciences. Sage, Thousand Oaks, CA

Stanley S, Hardie L (1998) Secular oscillations in the carbonate mineralogy of reef-building and sediment-producing organisms driven by tectonically forced shifts in sea- 
water chemistry. Palaeogeogr Palaeoclimatol Palaeoecol 144:3-19

Taylor PD, James NP, Bone Y, Kuklinski P, Kyser TK (2009) Evolving mineralogy of cheilostome bryozoans. Palaios 24:440-452

Waeschenbach A, Taylor PD, Littlewood DTJ (2012) A molecular phylogeny of bryozoans. Mol Phylogenet Evol 62:718-735

Warton DI, Hui FKC (2011) The arcsine is asinine: the analysis of proportions in ecology. Ecology 92:3-10

Weiner S, Dove PM (2003) An overview of biomineralization

Editorial responsibility: Roger Hughes,

Bangor, UK processes and the problem of the vital effect. Rev Mineral Geochem 54:1-29

Wendt DE (2000) Energetics of larval swimming and metamorphosis in four species of Bugula (Bryozoa). Biol Bull 198:346-356

Widdicombe S, Spicer JI (2008) Predicting the impact of ocean acidification on benthic biodiversity: What can animal physiology tell us? J Exp Mar Biol Ecol 366: 187-197

Winston JE (1977) Distribution and ecology of estuarine ectoprocts: a critical review. Chesap Sci 18:34-57

Submitted: January 22, 2014; Accepted: May 27, 2014

Proofs received from author(s): September 2, 2014 